\title{
Use natural soil amendments in improving hydro-physical properties and wheat crop production of a new reclaimed area, Sohag governorate, Egypt
}

\author{
Turky M. M., El-Sayed M. M. , Awad M. Y., Abdel-Mawgoud A. S. A. \\ Soils and Water Science Department, Faculty of Agriculture, Al-Azhar University, 71524 Assuit, Egypt
}

\begin{abstract}
A field trial was carried out at The Experimental Farm of Al-Sheikh Allam Al-Monshaah, Sohag governorate, Egypt which is located at $26^{\circ} 52^{-} 41^{\circ} \mathrm{N}$ latitude and $31^{\circ} 75^{\circ} 96^{\circ} \mathrm{E}$ longitude during two successive growth seasons of 2017/18 and 2018/19 to investigate some natural soil amendments (poultry manure, PM; farmyard, FYM; compost, CO ; mud rock, MR) with two application levels $(20$ and 40 ton/ fed) $(f e d=$ feddan $=0.420$ hectares $=1.037$ acres) to assess their effects on soil hydro-physical properties and to find the suitable application level for wheat crop production. The results showed that the soil texture differed from sand to loamy sand with slight no changes as a result of soil amendments applications (SA). The SA reduced the soil bulk density especially in the surface layer at high application level. They increased the saturation percentage, field capacity and available water. The positive effect of SA on the soil moisture constant could be arranged in the descending order of $\mathrm{PM}>\mathrm{CO}>\mathrm{MR}>\mathrm{FYM}$. The infiltration rate (IF) of surface layers differed from 0.17 to $0.68 \mathrm{~cm} / \mathrm{hr}$. as an average of both growth seasons. The IF rate increased as the amount of SA increased. It is considered slow for FYM, CO and MR treatments and moderately slow for PM treatment. The effect of SA on IF could be sorted in the descending order of $\mathrm{PM}>\mathrm{FYM}>\mathrm{CO}>\mathrm{MR}$. The main hydraulic conductivity (HC) of both seasons of the top soil $(50 \mathrm{~cm})$ varies from 0.05 to $0.17 \mathrm{~m} /$ day. It increased as the level of SA increased. It is also considered slow for FYM, CO and MR treatments and moderately slow for PM treatment. The effect of SA on the HC could be set in the descending order of $\mathrm{PM}>\mathrm{FYM}>\mathrm{CO}>\mathrm{MR}$.
\end{abstract}

Keywords: natural soil amendment, hydro-physical properties, wheat crop, new reclaimed area. 


\section{Introduction}

Since 20 years ago, the Egyptian government has extensive promoted the agricultural expansion into new lands located in the desert region. Sustainable agriculture in the new reclaimed area relies on organic amendments to achieve the nutrient requirements for grown crop plants. Currently, the Egyptian government has the strategic ambition of reclaiming 1.5 million feddan (feddan= 0.420 hectares $=1.037$ acres) in the desert. Egypt is at a cross road of starting a new era, the main challenges facing the government are green economy, human development and innovation (ECES and ENCC, 2014). In these desert areas, soil types and their properties are very much influenced by geomorphic and pedogenic factors. Generally, soils in the new lands are short of fertile nutrients (especially micronutrients), very low in organic matter, high alkalinity (high $\mathrm{pH}$ ), and have inferior physical properties and moisture characteristics. To sustain the productivity of soils particularly in these areas, soil amendments are important soil additives to improve soil physical, chemical and biological properties (Adesodun et al., 2005; Wafaa et al., 2016). Applications of organic amendments improve soil properties via increasing the soil organic matter content, which has a stimulatory effect on the structure and aggregate stability, thereby improving the aeration, buffering of soil reaction, water holding capacity, cation exchange capacity, and microbial activities (Awad, 2001; Adugna, 2016; Garg and Bahla, 2008; Tayebeh et al., 2010). Also, soil amendments have the ability to increase the available moisture content of the root zone, increase water holding capacity up to 400 times of its weight in water and release most of the water retained within the granules for growing plants (Eldardiry and Abd ElHady, 2015). In addition, some organic materials, particularly compost, farmyard, poultry manures as well as humic and molasses are sold as soil amendments and contain relatively low concentrations of actual nutrients (Awad, 2016; El-Farghal and El-Sherif, 2012). They release nutrients over a fairly long period; the potential drawback is that they may not release enough of their principal nutrient at a time to give the plant what it needs for best growth (Akanbi et al., 2005; Nyangani, 2010). Furthermore, they increase bacterial and fungal activities, particularly the mycrohizal fungi which alone make other soil nutrients more available to plants and reduce nutrient loss either from the soil through $\mathrm{N}$ leaching and denitrification or through the $\mathrm{P}$ sorption of nutrients (Zahir et al., 2007). Additions of these amendments to soils not only provide plant available nutrients on their decomposition but also offer an energy (carbon) source to the soil ecosystem and build soil fertility and structure in the long run (Karbout et al., 2015). Wheat (Triticum aestivum L.) is considered as the major cereal crop in the world in regarding the cultivated area and total production (Meena et al., 2018). It is the most important food crop and its high production is the ultimate goal need to meet the increasing population and growing demand for food. It provides an almost $20 \%$ of food calories for people in the world as well as in Egypt. Wheat is 
among the crops which its yield is limited by low nutrients availability in sand soils (Bameri et al., 2012). To maximize utilization, increase the productivity and sustainability of agriculture in these soils which are poor in their properties and nutrients, enhancements must be implementing of to modify their properties and release nutrients (Adeyemo et al., 2019; Awad et al., 2020). Therefore, this study aims to use some types of soil amendments for sustainable agriculture of new reclaimed soil and assess their effects on improving soil hydro-physical properties as well as to draw out the suitable application level for optimum utilization of such soils for wheat crop production.

\section{Materials and methods}

Two field investigation experiments were carried out at the Experimental Farm of
Al-Sheikh Allam Al-Monshaah, Sohag governorate, Egypt which is located at $26^{\circ} 52^{-} 41^{=} \mathrm{N}$ latitude and $31^{\circ} 75^{-} 96^{=} \mathrm{E}$ longitude during two successive growing winter seasons of 2017/18 and 2018/19 to assess the application of some soil amendments on the soil physical and hydraulic properties and improve the wheat production of a new reclaimed area. Some soil properties of the experimental site are present in Table (1). The experiment was laid out in a split plots design with three replications. The main plots were assigned to soil amendments type (poultry manure, farmyard, compost and mud rock) treatments they including the control were bounded with a buffer zone $(2 \mathrm{~m}$ width) to avoid the horizontal seepage. The split plots were allocated to their application level (20 and 40 ton/ fed) $(\mathrm{fed}=$ feddan $=0.420$ hectares $=1.037$ acres).

Table (1): Some soil properties of the experimental site.

\begin{tabular}{|l|c|c|c|c|}
\hline \multirow{2}{*}{ Property } & \multicolumn{2}{|c|}{$2017 / 18$ season } & \multicolumn{2}{c|}{$2018 / 19$ season } \\
\cline { 2 - 5 } & \multicolumn{2}{|c|}{ Soil depth $(\mathrm{cm})$} & \multicolumn{2}{c|}{ Soil depth $(\mathrm{cm})$} \\
\cline { 2 - 5 } & $0-25$ & $25-50$ & $0-25$ & $25-50$ \\
\hline $\mathrm{pH}(1: 2.5)$ & 7.98 & 8.02 & 8.05 & 8.08 \\
\hline $\mathrm{EC}_{\mathrm{e}}(\mathrm{dS} / \mathrm{m})$ & 6.85 & 6.45 & 7.10 & 6.65 \\
\hline $\mathrm{CaCO}(\%)$ & 47.25 & 51.35 & 46.70 & 51.85 \\
\hline $\mathrm{OM}(\%)$ & 0.16 & 0.12 & 0.18 & 0.14 \\
\hline Sand $(\%)$ & 85.50 & 84.00 & 86.00 & 85.20 \\
\hline Silt $(\%)$ & 13.00 & 14.00 & 12.00 & 13.00 \\
\hline Clay $(\%)$ & 1.50 & 2.00 & 2.00 & 1.80 \\
\hline Texture class & sand & sand & sand & sand \\
\hline SP & 28.00 & 29.50 & 29.00 & 30.00 \\
\hline FC $(\%)$ & 15.20 & 15.45 & 15.50 & 15.85 \\
\hline WP $(\%)$ & 7.25 & 7.42 & 7.33 & 7.50 \\
\hline
\end{tabular}


The used materials are available in big quantities in Sohag governorate. The chemical analysis of the tested soil amendments are shown in Table (2). Each main plot was $8 \mathrm{~m}$ in length and 5 $\mathrm{m}$ in width having an area of $40 \mathrm{~m}^{2}$ (almost 1/100 fed). The mud rocks, poultry manure, farmyard manure and compost were added to soil during land preparation. In addition, a control plot was executed with no additions of any soil amendment.

Table (2): Some chemical analyses of the investigated soil amendments.

\begin{tabular}{|l|c|c|c|c|c|c|}
\hline Amendments & $\begin{array}{c}(\mathrm{EC} \mathrm{1:2.5)} \\
(\mathrm{dS} / \mathrm{m})\end{array}$ & $\begin{array}{c}\mathrm{pH} \\
(1: 2.5)\end{array}$ & $\begin{array}{c}\mathrm{OM} \\
(\%)\end{array}$ & $\begin{array}{c}\text { Total N } \\
(\%)\end{array}$ & $\begin{array}{c}\text { Total P } \\
(\%)\end{array}$ & $\begin{array}{c}\text { Total K } \\
(\%)\end{array}$ \\
\hline Poultry manure (PM) & 5.80 & 6.50 & 56.80 & 4.100 & 2.700 & 2.100 \\
\hline Farmyard manure (FYM) & 6.80 & 7.50 & 35.50 & 1.200 & 0.900 & 1.500 \\
\hline Compost (CO) & 2.70 & 8.60 & 65.50 & 1.850 & 0.520 & 1.350 \\
\hline Mud rock (MR) & 1.50 & 7.60 & 0.50 & 0.007 & 0.013 & 0.084 \\
\hline
\end{tabular}

In the winter seasons of $2017 / 18$ and 2018/19, wheat seeds (Triticum aestivum vulgar) were sown in rows of $800 \mathrm{~cm}$ long and $15 \mathrm{~cm}$ apart on November 20 under the flooding irrigation system (each plot included 33 rows). All the agriculture practices were applied as commonly used for growing wheat and carried out according to the recommendations set by the Ministry of Agriculture. Nitrogen fertilizer was applied in the form of ammonium nitrate $(33.5 \% \mathrm{~N})$ at a level of $120 \mathrm{~kg} / \mathrm{fed}$ in two equal doses, the first one before the post planting irrigation and the second dose at the tillering stage (before the second irrigation). Phosphorus fertilizer in the form of calcium super phosphate $(15.5 \%$ $\mathrm{P}_{2} \mathrm{O}_{5}$ ) was added at a level of $100 \mathrm{~kg} / \mathrm{fed}$. in one dose during soil preperation. Potassium fertilizer in the form of potassium sulphate $\left(\begin{array}{lll}48 \% & \left.\mathrm{~K}_{2} \mathrm{O}\right) & \text { was }\end{array}\right.$ supplemented at a level of $50 \mathrm{~kg} / \mathrm{fed}$ in two equal portions at the same time of adding nitrogen fertilizer. At harvesting stage of wheat plants, (135 days after planting for each season), disturbed and undisturbed soil samples were collected from the plots of each treatment including the control at depths of 0-30 and $30-60 \mathrm{~cm}$. and kept for some soil analyses. The disturbed soil samples were air dried, gently crushed and sieved through a $2 \mathrm{~mm}$ sieve. The soil chemical properties were measured according to Page et al. (1982) and the physical properties were carried out according to Klute (1986). At harvest time, four square meters $(2 \mathrm{~m} \times 2 \mathrm{~m})$ from the centric area of each plot were used to estimate the grain and straw yield of wheat plant and then the recorded values were calculated for the whole feddan. Data were statistically analysis and subjected to analysis of variance (ANOVA) using SPSS statistics, Version 21. 


\section{Results and Discussion}

\subsection{Soil physical properties}

\subsubsection{Soil texture}

The soil particles size distribution of the study area showed almost slight changes related to the investigated treatments after both growing seasons (Table 3). It is well known that soil texture is considered a constant physical property that might not be changed through centuries. The sand fraction of this soil varied from 83.2 to $86.4 \%$ in the surface layer and from 81.5 to $85 \%$ in the subsurface layer it obviously decreased with depth in all treatments. The silt fraction differed from 9.0 to $15.2 \%$ in the surface layer and from 10 to $16 \%$ in the subsurface one. In addition, it increased with depth. Also, the clay fraction ranged from 0.8 to $5.6 \%$ in the surface layer and from 1.0 to $6.0 \%$ in the subsurface one and increased with depth. As a result of the treatments, the soil texture apparently changed from sand and loamy sand due to the application of treatments, especially with increasing the application level.

Table (3): Influence of soil amendments applications on soil particle size distribution, texture as averages of both growth seasons of 2017/ 18 and 2018/19.

\begin{tabular}{|c|c|c|c|c|c|c|}
\hline Treatments & $\begin{array}{l}\text { Application level } \\
\text { (ton/fed) }\end{array}$ & $\begin{array}{c}\text { Depth } \\
(\mathrm{cm})\end{array}$ & $\begin{array}{l}\text { Clay } \\
(\%)\end{array}$ & $\begin{array}{l}\text { Silt } \\
(\%)\end{array}$ & $\begin{array}{c}\text { Sand } \\
(\%)\end{array}$ & Texture grade \\
\hline \multirow{2}{*}{ Control ( C) } & \multirow{2}{*}{------- } & $0-25$ & 0.8 & 13.6 & 85.6 & Sand \\
\hline & & $25-50$ & 1.0 & 14.0 & 85.0 & Sand \\
\hline \multirow{4}{*}{ Poultry manure (PM) } & \multirow{2}{*}{20} & $0-25$ & 3.2 & 12.0 & 84.8 & Loamy sand \\
\hline & & $25-50$ & 3.5 & 12.5 & 84.0 & Loamy sand \\
\hline & \multirow{2}{*}{40} & $0-25$ & 0.8 & 15.2 & 84.0 & Loamy sand \\
\hline & & $25-50$ & 1.9 & 16.0 & 82.1 & Loamy sand \\
\hline \multirow{4}{*}{ Farm yard manure (FYM) } & \multirow{2}{*}{20} & $0-25$ & 1.6 & 12.0 & 86.4 & Sand \\
\hline & & $25-50$ & 2.2 & 13.0 & 84.8 & Loamy sand \\
\hline & \multirow{2}{*}{40} & $0-25$ & 0.8 & 15.2 & 84.0 & Loamy sand \\
\hline & & $25-50$ & 1.5 & 16.0 & 82.5 & Loamy sand \\
\hline \multirow{4}{*}{ Compost (CO) } & \multirow{2}{*}{20} & $0-25$ & 2.4 & 11.2 & 86.4 & Sand \\
\hline & & $25-50$ & 2.8 & 13.0 & 84.2 & Loamy sand \\
\hline & \multirow{2}{*}{40} & $0-25$ & 0.8 & 12.8 & 86.4 & Sand \\
\hline & & $25-50$ & 1.6 & 14.0 & 84.4 & Loamy sand \\
\hline \multirow{4}{*}{ Mud rocks (MR) } & \multirow{2}{*}{20} & $0-25$ & 5.6 & 9.0 & 85.4 & Sand \\
\hline & & $25-50$ & 6.0 & 10.0 & 84.0 & Loamy sand \\
\hline & \multirow{2}{*}{40} & $0-25$ & 1.6 & 15.2 & 83.2 & Loamy sand \\
\hline & & $25-50$ & 2.5 & 16.0 & 81.5 & Loamy sand \\
\hline \multirow{4}{*}{ Humic acids } & \multirow{2}{*}{$\mathrm{HA}_{1}$} & $0-25$ & 0.8 & 14.4 & 84.8 & Loamy sand \\
\hline & & $25-50$ & 2.0 & 15.0 & 83.0 & Loamy sand \\
\hline & \multirow{2}{*}{$\mathrm{HA}_{2}$} & $0-25$ & 2.4 & 19.2 & 78.4 & Loamy sand \\
\hline & & $25-50$ & 3.0 & 18.0 & 79.0 & Loamy sand \\
\hline \multirow{4}{*}{ Molasses } & \multirow{2}{*}{$\mathrm{MS}_{1}$} & $0-25$ & 4.0 & 11.2 & 84.8 & Loamy sand \\
\hline & & $25-50$ & 4.5 & 12.0 & 83.5 & Loamy sand \\
\hline & \multirow{2}{*}{$\mathrm{MS}_{2}$} & $0-25$ & 0.8 & 11.2 & 88.0 & Sand \\
\hline & & $25-50$ & 2.0 & 14.0 & 84.0 & Loamy sand \\
\hline
\end{tabular}


It is worth to mention that the values of clay fraction for all soil amendment treatments were less than 5\% except that of mud rock at 20 ton/fed. This might be due to the direct effect of applied mud rock as a soil conditioner which contains higher amount of clay fraction. The increase in clay fraction was at the expense of silt fraction. Also, it was observed that the values of silt fraction for all soil conditioner treatments were higher than $10 \%$ except that of mud rock application at 20 ton/fed.

\subsubsection{Soil bulk density}

Soil bulk density (BD) values were affected by soil amendments application especially in the surface layer with the high application level (Table 4). As average values of both growth seasons, the soil bulk density values differed from 1.34 to $1.63 \mathrm{Mg} / \mathrm{m}^{3}$ in the surface layer and from 1.42 to $1.71 \mathrm{Mg} / \mathrm{m}^{3}$ in the sub surface layer. All soil amendments caused reductions in the soil BD especially poultry manure (PM) treatment at $20 \mathrm{ton} /$ fed level that reduced the BD in the surface layer by $17.79 \%$ and in the subsurface one $14.62 \%$. The soil $\mathrm{BD}$ reductions for $\mathrm{PM}$ treatment at 40 ton/fed level were higher than those of 20 ton/fed one. The soil BD reductions were 19.38 and $17.25 \%$ for the surface and subsurface layers, respectively. In addition, the relative reductions in BD were $14.46,13.23$ and $13.23 \%$ for FYM, $\mathrm{CO}$ and MR treatments at $20 \mathrm{ton} / \mathrm{fed}$ level respectively, in the surface layer.
The respective BD values for FYM, CO and MR treatments at 40 ton/fed level were $15.69,14.77$ and $14.77 \%$. Generally, the effect of soil treatments applications on soil bulk density reduction could be arranged in the descending order of $\mathrm{PM}>\mathrm{FYM}>\mathrm{CO}>$ MR in both seasons. Agbede et al. (2008) reported that application of PM improved most of soil physical properties. The PM application encourages to stabilize the soil structure, thereby reducing the soil bulk density, increasing porosity, and infiltration rate and water retention. Organic matter application can improve soil structure and aeration, reduce soil bulk density, enhance water infiltration and retention, and increase microbial populations (Agbede et al., 2013). The observed reduction in BD may be related to the organic material properties such as particle size, active surface area, porosity and soil properties. Furthermore, the ability of organic materials to form soil aggregates in combination with soil particles leads to a decrease in $\mathrm{BD}$ values (Šimanský et al., 2016).

\subsubsection{Soil porosity}

All soil amendments and their application level realized positive effects on the soil porosity which increased with each type and its level (Table 4). The soil porosity ranged from 38.33 to $47.91 \%$ in the surface layer while it differed from 35.59 to $45.47 \%$ in the subsurface one. Generally, it decreased with soil depth. The application of PM at 40 ton/fed level 
resulted the highest porosity values for both the surface and subsurface layers. However, the lowest porosity values were recorded for the control treatment. As average values of both growth seasons, the relative increases of the soil porosity were $17.01,16.32,15.68$ and $16.45 \%$ for PM, FYM, CO and MR treatments at 20 ton/fed level, respectively, in the surface. Furthermore, their respective soil porosity increases at the $40 \mathrm{ton} /$ fed level were 20.0, 17.91, 16.69 and $17.80 \%$. The soil amendments could be sorted according to their effect on the soil porosity increases in the descending order of $\mathrm{PM}>\mathrm{FYM}>\mathrm{CO}>$ MR. As a fact the soil porosity increase with decreasing the soil bulk density (BD).This relation is confirmed by these results of the soil bulk density and porosity (Miglierina et al., 2015). The porosity increases as a result of application of soil amendments could be due to the improvement of soil structure (Šimanský, 2016). One of the most important mechanisms involved in the soil structure formation causes an increase in the total soil porosity due to organic material applications is the ability of organic material itself to associate with the soil mineral particles directly (Lehmann et al., 2011) or through $\mathrm{Ca}$ bridges (Kobierski et al., 2018; Šimanský and Jonczak, 2020).

Table (4): Influence of some soil amendments applications to the soil bulk density and soil porosity after wheat harvest during the growth seasons of 2017/ 18 and 2018/ 19.

\begin{tabular}{|c|c|c|c|c|c|c|c|c|c|c|c|c|c|}
\hline \multirow[b]{2}{*}{ Treatment } & \multirow{2}{*}{$\begin{array}{c}\text { Application } \\
\text { level } \\
\text { (ton/fed) }\end{array}$} & \multirow{2}{*}{$\begin{array}{l}\text { Depth } \\
(\mathrm{cm})\end{array}$} & \multicolumn{3}{|c|}{ Particles density $\left(\mathrm{Mg} / \mathrm{m}^{3}\right)$} & \multicolumn{4}{|c|}{ Bulk density $\left(\mathrm{Mg} / \mathrm{m}^{3}\right)$} & \multicolumn{4}{|c|}{ Porosity (\%) } \\
\hline & & & $2017 / 18$ & $2018 / 19$ & Mean & $2017 / 18$ & 2018/19 & Mean & $\begin{array}{c}\text { Relative } \\
\text { reduction }(\%)\end{array}$ & $2017 / 18$ & $2018 / 19$ & Mean & $\begin{array}{c}\text { Relative } \\
\text { increase (\%) }\end{array}$ \\
\hline \multirow{2}{*}{ Control ( C) } & ------ & $0-25$ & 2.63 & 2.64 & 2.64 & 1.65 & 1.60 & 1.63 & ------- & 37.26 & 39.39 & 38.33 & ------ \\
\hline & ------ & $25-50$ & 2.65 & 2.66 & 2.66 & 1.72 & 1.70 & 1.71 & 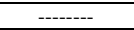 & 35.09 & 36.09 & 35.59 & $\begin{array}{ll}-\cdots+-- \\
--1\end{array}$ \\
\hline \multirow{4}{*}{$\begin{array}{l}\text { Poultry manure } \\
\text { (PM) }\end{array}$} & \multirow{2}{*}{20} & $0-25$ & 2.48 & 2.50 & 2.49 & 1.35 & 1.33 & 1.34 & 17.79 & 45.56 & 46.80 & 46.18 & 17.01 \\
\hline & & $25-50$ & 2.59 & 2.58 & 2.59 & 1.47 & 1.45 & 1.46 & 14.62 & 43.24 & 43.80 & 43.52 & 18.22 \\
\hline & \multirow{2}{*}{40} & $0-25$ & 2.51 & 2.52 & 2.52 & 1.32 & 1.30 & 1.31 & 19.63 & 47.41 & 48.41 & 47.91 & 20.00 \\
\hline & & $25-50$ & 2.59 & 2.60 & 2.60 & 1.43 & 1.40 & 1.42 & 17.25 & 44.79 & 46.15 & 45.47 & 21.72 \\
\hline \multirow{4}{*}{$\begin{array}{l}\text { Farm yard } \\
\text { manure (FYM) }\end{array}$} & \multirow{2}{*}{20} & $0-25$ & 2.55 & 2.58 & 2.57 & 1.40 & 1.38 & 1.39 & 14.72 & 45.10 & 46.51 & 45.80 & 16.32 \\
\hline & & $25-50$ & 2.60 & 2.59 & 2.60 & 1.52 & 1.50 & 1.51 & 11.70 & 41.54 & 42.08 & 41.81 & 14.87 \\
\hline & \multirow{2}{*}{40} & $0-25$ & 2.56 & 2.58 & 2.57 & 1.37 & 1.37 & 1.37 & 15.95 & 46.48 & 46.90 & 46.69 & 17.91 \\
\hline & & $25-50$ & 2.60 & 2.61 & 2.61 & 1.49 & 1.51 & 1.50 & 12.28 & 42.69 & 42.15 & 42.42 & 16.09 \\
\hline \multirow{4}{*}{ Compost (CO) } & \multirow{2}{*}{20} & $0-25$ & 2.58 & 2.59 & 2.59 & 1.40 & 1.42 & 1.41 & 13.50 & 45.74 & 45.17 & 45.46 & 15.68 \\
\hline & & $25-50$ & 2.60 & 2.61 & 2.61 & 1.56 & 1.53 & 1.55 & 9.65 & 40.00 & 41.38 & 40.69 & 12.53 \\
\hline & \multirow{2}{*}{40} & $0-25$ & 2.56 & 2.57 & 2.57 & 1.38 & 1.39 & 1.39 & 15.03 & 46.09 & 45.91 & 46.00 & 16.69 \\
\hline & & $25-50$ & 2.58 & 2.60 & 2.59 & 1.54 & 1.55 & 1.55 & 9.65 & 40.31 & 40.38 & 40.35 & 11.79 \\
\hline \multirow{4}{*}{$\begin{array}{l}\text { Mud rocks } \\
\text { (MR) }\end{array}$} & \multirow{2}{*}{20} & $0-25$ & 2.60 & 2.61 & 2.61 & 1.39 & 1.43 & 1.41 & 13.50 & 46.54 & 45.21 & 45.87 & 16.45 \\
\hline & & $25-50$ & 2.60 & 2.62 & 2.61 & 1.54 & 1.58 & 1.56 & 8.77 & 40.77 & 39.69 & 40.23 & 11.53 \\
\hline & \multirow{2}{*}{40} & $0-25$ & 2.59 & 2.60 & 2.60 & 1.37 & 1.40 & 1.39 & 15.03 & 47.10 & 46.15 & 46.63 & 17.80 \\
\hline & & $25-50$ & 2.62 & 2.62 & 2.62 & 1.52 & 1.58 & 1.55 & 9.36 & 41.98 & 39.69 & 40.84 & 12.85 \\
\hline
\end{tabular}

Tokova et al. (2020) indicated that a biochar applied at $20 \mathrm{t} \mathrm{ha}^{-1}$ without fertilizers significantly reduced the soil bulk density by $12 \%$ and increased the porosity by $13 \%$. Also a gradual increase in the biochar dose gradually decreased the bulk density.

\subsection{Soil moisture constants}

Soil water is very essential for the proper plant growth and development. Soil 
moisture constants are necessary to determine the moisture that is present in the soil under any certain condition and at any instant of time. Soil water moves occurs mainly through three types including saturated, unsaturated and water vapor movement. Infiltration and other modes of water entry into the soil contribute to the formation of water reservoir in soil (Chauvin et al., 2011).

\subsubsection{Saturation percentage (SP)}

In both growth seasons, soil amendments applications pronounced increases in the SP of the soil (Table 5). The SP of the studied soil ranged from 33 to $49 \%$ in the surface layer and from 32 to $41 \%$ in the subsurface layer. It decreased with soil depth except with using the mud rock treatment which with the increased depth the reverse was true regardless the soil conditioner type or level. The relative mean increases of SP values were 27, 13.8, 20.3 and $14.31 \%$ for PM, FYM, CO and MR treatments, respectively, over the applied level and soil depth. The positive effect of soil amendments application on SP could be arranged in the descending order of $\mathrm{PM}>\mathrm{CO}>\mathrm{MR}$ $>$ FYM.

\subsubsection{Field capacity (FC)}

In both growth seasons, cause increases occurred in the FC as a result of soil amendments application compared to the control treatment (Table 5). In general, the FC differed from 19.0 to $25.8 \%$ in the surface layer as average values of both seasons and from 19.5 to $23.1 \%$ in the subsurface layer one. It decreased with soil depth (Table 5). The relative mean increases of the FC over the treatment level and soil depth were 17.7, 10.8, 12.8 and $10.0 \%$ for PM, FYM, CO and MR treatments, respectively. The effect of soil amendments application on FC increases could be set in the descending order of $\mathrm{PM}>\mathrm{CO}>\mathrm{FYM}>\mathrm{MR}$. Habashy and Ewees (2011) found that the addition of an organo-mineral fertilizer (OMF) compost to a saline soil encouraged the creation of medium and micro-pores among simple packing sand particles, and in turn increasing the capillary potential. They attributed this result to an increase in soil moisture content at field capacity and then the available water content due to the increase in the total fibers $(32.3-33.1 \%)$ and WHC of OMF compost (6.18-6.32 g water/g OMF compost). The effects of OMF components on improving soil properties such as aggregation, aeration, permeability, and WHC were positive, which led to maintain the appropriate water content in the soil and hence increasing the activity of the immune plant system.

\subsubsection{Wilting point (WP)}

Increases in the moisture content at the WP occurred in both seasons due to the application of the studied amendments compared to the control treatment (Table 5). 
Table (5): Effect of some soil amendments application on soil moisture constants after wheat harvest during the growth seasons of 2017/ 18 and 2018/ 19 .

\begin{tabular}{|c|c|c|c|c|c|c|c|c|c|c|c|c|c|c|c|c|c|c|}
\hline \multirow{2}{*}{ Treatments } & \multirow{2}{*}{$\begin{array}{c}\text { Applicati } \\
\text { on level } \\
\text { (ton/fed) }\end{array}$} & \multirow{2}{*}{$\begin{array}{l}\text { Soil } \\
\text { depth } \\
\text { (cm) }\end{array}$} & \multicolumn{4}{|c|}{ SP (\%) } & \multicolumn{4}{|c|}{$\mathrm{FC}(\%)$} & \multicolumn{4}{|c|}{ WP (\%) } & \multicolumn{4}{|c|}{ AWC $(\%)$} \\
\hline & & & $2017 / 18$ & $2018 / 19$ & mean & R.I & $2017 / 18$ & $2018 / 19$ & mean & R.I & $2017 / 18$ & 2018/19 & mean & R.I & $2017 / 18$ & $2018 / 19$ & mean & R.I \\
\hline \multirow{2}{*}{ Control (C) } & $\begin{array}{ll}------ \\
\end{array}$ & $0-25$ & 32.0 & 34.0 & 33.0 & ----- & 18.5 & 19.4 & 19.0 & ----- & 7.5 & 8.5 & 8.0 & ----- & 11.0 & 10.9 & 11.0 & ----- \\
\hline & ----- & $25-50$ & 33.0 & 31.0 & 32.0 & - & 19.8 & 19.2 & 19.5 & ------ & 8.3 & 7.8 & 8.0 & -a---- & 11.6 & 11.5 & 11.5 & $-\cdots$ \\
\hline \multirow{4}{*}{$\begin{array}{l}\text { Poultry } \\
\text { manure } \\
\text { (PM) }\end{array}$} & \multirow{2}{*}{20} & $0-25$ & 45.0 & 46.0 & 45.5 & 27.5 & 25.0 & 26.5 & 25.8 & 26.2 & 11.1 & 11.3 & 11.2 & 28.6 & 13.9 & 15.2 & 14.6 & 24.4 \\
\hline & & $25-50$ & 42.0 & 41.0 & 41.5 & 22.9 & 23.5 & 22.6 & 23.1 & 15.4 & 10.5 & 10.3 & 10.4 & 22.9 & 13.0 & 12.4 & 12.7 & 9.3 \\
\hline & \multirow{2}{*}{40} & $0-25$ & 41.0 & 43.0 & 42.0 & 21.4 & 21.6 & 23.6 & 22.6 & 15.9 & 10.3 & 10.4 & 10.3 & 22.5 & 11.4 & 13.2 & 12.3 & 10.4 \\
\hline & & $25-50$ & 40.0 & 39.0 & 39.5 & 19.0 & 22.3 & 22.4 & 22.4 & 12.8 & 10.2 & 10.5 & 10.4 & 22.7 & 12.1 & 11.9 & 12.0 & 4.2 \\
\hline \multirow{4}{*}{$\begin{array}{l}\text { Farm yard } \\
\text { manure } \\
\text { (FYM) }\end{array}$} & \multirow{2}{*}{20} & $0-25$ & 39.0 & 38.0 & 38.5 & 14.3 & 22.4 & 21.8 & 22.1 & 14.0 & 9.8 & 9.5 & 9.6 & 16.9 & 12.7 & 12.3 & 12.5 & 11.8 \\
\hline & & $25-50$ & 36.0 & 37.0 & 36.5 & 12.3 & 20.6 & 21.2 & 20.9 & 6.7 & 9.0 & 9.3 & 9.1 & 12.3 & 11.6 & 12.0 & 11.8 & 2.3 \\
\hline & \multirow{2}{*}{40} & $0-25$ & 37.0 & 36.0 & 36.5 & 9.6 & 21.2 & 21.0 & 21.1 & 10.0 & 9.3 & 9.0 & 9.1 & 12.3 & 12.0 & 12.0 & 12.0 & 8.1 \\
\hline & & $25-50$ & 39.0 & 40.0 & 39.5 & 19.0 & 22.8 & 21.5 & 22.2 & 12.0 & 9.8 & 10.0 & 9.9 & 19.0 & 13.1 & 11.5 & 12.3 & 6.3 \\
\hline \multirow{4}{*}{$\begin{array}{l}\text { Compost } \\
\text { (CO) }\end{array}$} & \multirow{2}{*}{20} & $0-25$ & 38.0 & 39.0 & 38.5 & 14.3 & 21.8 & 22.4 & 22.1 & 14.0 & 9.5 & 9.8 & 9.6 & 16.9 & 12.3 & 12.7 & 12.5 & 11.8 \\
\hline & & $25-50$ & 36.0 & 37.0 & 36.5 & 12.3 & 20.6 & 21.3 & 21.0 & 6.9 & 9.0 & 9.3 & 9.1 & 12.3 & 11.6 & 12.1 & 11.8 & 2.7 \\
\hline & \multirow{2}{*}{40} & $0-25$ & 50.0 & 48.0 & 49.0 & 32.7 & 22.5 & 22.8 & 22.7 & 16.1 & 11.5 & 11.8 & 11.7 & 31.3 & 11.0 & 11.0 & 11.0 & 0.0 \\
\hline & & $25-50$ & 40.0 & 42.0 & $\begin{array}{l}41.0 \\
\end{array}$ & 22.0 & 22.0 & 23.2 & 22.6 & 13.7 & 10.0 & 10.5 & 10.3 & 22.0 & 12.0 & 12.7 & 12.4 & 6.9 \\
\hline \multirow{4}{*}{$\begin{array}{l}\text { Mud rocks } \\
\text { (MR) }\end{array}$} & \multirow{2}{*}{20} & $0-25$ & 38.0 & 37.0 & 37.5 & 12.0 & 22.8 & 20.2 & 21.5 & 11.6 & 9.5 & 9.3 & 9.4 & 14.7 & 13.3 & 11.0 & $\begin{array}{ll}12.1 \\
\end{array}$ & 9.3 \\
\hline & & $25-50$ & 41.0 & 40.0 & 40.5 & 21.0 & 23.6 & 22.2 & 22.9 & 14.8 & 10.3 & 10.0 & 10.1 & 21.0 & 13.4 & 12.2 & 12.8 & 10.0 \\
\hline & \multirow{2}{*}{40} & $0-25$ & 36.0 & 37.0 & 36.5 & 9.6 & 21.6 & 20.2 & 20.9 & 9.1 & 9.0 & 9.3 & 9.1 & 12.3 & 12.6 & 11.0 & 11.8 & 6.6 \\
\hline & & $25-50$ & 37.0 & 38.0 & 37.5 & 14.7 & 20.2 & 20.4 & 20.3 & 3.9 & 9.3 & 9.5 & 9.4 & 14.7 & 11.0 & 10.9 & 10.9 & -5.3 \\
\hline
\end{tabular}

The average WP value of both season changed from 8.0 to $11.7 \%$ the WP value of decreased with soil depth expect those of MR treated on. The relative average increases in values over the soil depth and the amendments level the WP the treated sort with tested amendments were 24.2, 15.1, 20.6 and $15.7 \%$ for PM, FYM, CO and MR treatments, respectively compared to the control. The WP increases due to investigated amendments could be sorted in the descending order of $\mathrm{PM}>\mathrm{CO}>\mathrm{MR}>$ FYM. It was noticed that the WP values however, followed almost the same trend of FC values in both growing seasons. Toková et al. (2020) displayed significant decrease in the permanent wilting point (WP) after biochar reapplication.

\subsubsection{Available water (AW)}

The application of the investigated treatments in both growth seasons gave increases in the AW content compared to the control treatment (Table 5). As an average of both season the AW content varied from 11.0 to $14.6 \%$. However, it did not show any trend with soil depth. The relative mean increase in the AW content over the depth and application level were 12.2, 7.4, 5.6 and $5.4 \%$ for PM, FYM, CO and MR treatments, respectively, compared to the control treatment. Lu (2014) exhibited a positive effect of biochar application on the soil available water capacity for plants resulting in an increase in crop yields. Furthermore Toková et al. (2020) revealed that the higher the plant available water (PAW) values for a given soil, the greater the capacity of soil pores for water is to be available to plants. Their results showed that all biochar treatments increased the PAW in a range from 20 up to $49 \%$. 


\subsection{Some hydraulic soil properties}

Soil moisture is an important control on hydrologic function, as it governs vertical fluxes from and to the atmosphere, groundwater recharge, and lateral fluxes through the soil. Soil hydraulic properties are essential in irrigation and drainage studies for closing water balance equation, for predicting leaching of nutrients, for water supply to plants, and for other agronomical and environmental applications (Vereecken $e t$ al., 2008).

\subsubsection{Soil infiltration (IF)}

The investigated soil amendments caused increases in the IF rate values of the studied soil in both seasons compared to the control treatment (Table 6). The mean IF rate of surface layers in both seasons ranged from 0.17 to $0.68 \mathrm{~cm} / \mathrm{hr}$. In addition it increased as the applied level of the soil amendments increased. According to Hillel (1982), the infiltration rate is considered slow for the soil treated with FYM, CO and MR and moderately slow for PM amended soil. The increases in the IF rate related to the applied amendments could be arranged in the descending order of $\mathrm{PM}>\mathrm{FYM}>$ $\mathrm{CO}>\mathrm{MR}$. The obtained results coincide with those of the soil bulk density and soil porosity that were previously mentioned (Table 4). It is noticed that the increase in the soil infiltration rate as a result of the soil amendments application is attributed to its an positive effect on the redacting it soil bulk density and consequently increasing the soil porosity. The progressive improvement in the soil bulk density (reduction) and porosity (increases) due to amendment application caused faster movement of water through the soil profile that reflect on the soil infiltration rate. Agbede et al. (2008) pointed out that the application of poultry manure reduced the soil bulk density and increased the soil porosity which enhanced infiltration phenomenon. Li et al. (2011) also showed that the poultry litter and livestock manure amendment increased soil macro-pore and meso-pore volumes and decreased soil micro-pore volumes which enhance water infiltration sight. Moreover, Wanniarachchi et al. (2019) mentioned that the soil amendments can influence the soil hydrology such as reducing the infiltration and increasing surface runoff, carefully monitored application of soil amendments is recommended.

\subsubsection{Hydraulic conductivity $(H C)$}

In both growing seasons, increases in the $\mathrm{HC}$ of the soil took place due to application of soil amendments in both growth seasons compared to the control treatment (Table 6). In general, the average $\mathrm{HC}$ values of the top soil $(50 \mathrm{~cm})$ in both growth seasons changed from 0.05 to $0.17 \mathrm{~m} /$ day as a result of applying the soil amendments. The addition it increased as the added level of soil amendments increased. According to O'Neal (1952), the hydraulic 
conductivity is considered slow for this soil amended with FYM, CO and MR treatments and moderately slow for that amended with PM treatment.

Table (6): Impact of soil amendments applications on some soil hydraulic properties of the top soil $(50 \mathrm{~cm})$ after wheat harvest during the growth seasons of 2017/ 18 and 2018/ 19 .

\begin{tabular}{|c|c|c|c|c|c|c|c|c|c|c|c|c|c|}
\hline \multirow{3}{*}{ Treatment } & \multirow{3}{*}{$\begin{array}{c}\text { Applicati } \\
\text { on level } \\
\text { (ton/fed) }\end{array}$} & \multicolumn{6}{|c|}{ Infiltration rate $(\mathrm{cm} \backslash \mathrm{h})$} & \multicolumn{6}{|c|}{ Hydraulic conductivity ( $\mathrm{m} \backslash$ day) } \\
\hline & & \multicolumn{2}{|c|}{$2017 / 18$} & \multicolumn{2}{|c|}{$2018 / 19$} & \multicolumn{2}{|c|}{ mean } & \multicolumn{2}{|c|}{$2017 / 18$} & \multicolumn{2}{|c|}{$2018 / 19$} & \multicolumn{2}{|c|}{ mean } \\
\hline & & Value & \begin{tabular}{|c|} 
Categor \\
$\mathrm{y}$
\end{tabular} & Value & Category & Value & Category & Value & Category & Value & Category & Value & Category \\
\hline Control (C) & $\begin{array}{ll}------ \\
\end{array}$ & 0.16 & $\mathrm{~S}$ & 0.18 & $\mathrm{~S}$ & 0.17 & $\mathrm{~S}$ & 0.05 & $\mathrm{~S}$ & 0.05 & $\mathrm{~S}$ & 0.05 & $\mathrm{~S}$ \\
\hline \multirow{2}{*}{$\begin{array}{l}\text { Poultry manure } \\
\text { (PM) }\end{array}$} & 20 & 0.59 & MS & 0.62 & MS & 0.61 & MS & 0.15 & MS & 0.17 & MS & 0.16 & MS \\
\hline & 40 & 0.65 & MS & 0.70 & MS & 0.68 & MS & 0.16 & MS & 0.17 & MS & 0.17 & MS \\
\hline \multirow{2}{*}{$\begin{array}{l}\text { Farm yard } \\
\text { manure (FYM) }\end{array}$} & 20 & 0.41 & $\mathrm{~S}$ & 0.44 & $\mathrm{~S}$ & 0.43 & $\mathrm{~S}$ & 0.11 & $\mathrm{~S}$ & 0.11 & $\mathrm{~S}$ & 0.11 & $\mathrm{~S}$ \\
\hline & 40 & 0.50 & $\mathrm{~S}$ & 0.48 & $\mathrm{~S}$ & 0.49 & $\mathrm{~S}$ & 0.13 & MS & 0.13 & MS & 0.13 & MS \\
\hline \multirow{2}{*}{ Compost (CO) } & 20 & 0.33 & $\mathrm{~S}$ & 0.35 & $\mathrm{~S}$ & 0.34 & $\mathrm{~S}$ & 0.10 & $\mathrm{~S}$ & 0.10 & $\mathrm{~S}$ & 0.10 & $\mathrm{~S}$ \\
\hline & 40 & 0.38 & $\mathrm{~S}$ & 0.40 & $\mathrm{~S}$ & 0.39 & $\mathrm{~S}$ & 0.10 & $\mathrm{~S}$ & 0.11 & $\mathrm{~S}$ & 0.11 & $\mathrm{~S}$ \\
\hline \multirow{2}{*}{ Mud rocks (MR) } & 20 & 0.26 & $\mathrm{~S}$ & 0.25 & $\mathrm{~S}$ & 0.26 & $\mathrm{~S}$ & 0.07 & $\mathrm{~S}$ & 0.08 & $\mathrm{~S}$ & 0.08 & $\mathrm{~S}$ \\
\hline & 40 & 0.32 & $\mathrm{~S}$ & 0.30 & $\mathrm{~S}$ & 0.31 & $\mathrm{~S}$ & 0.09 & $\mathrm{~S}$ & 0.08 & $\mathrm{~S}$ & 0.09 & $\mathrm{~S}$ \\
\hline
\end{tabular}

$\mathrm{S}=$ slow, $\mathrm{MS}=$ moderately slow.

The application effect of soil amendments on the hydraulic conductivity of the studied soil could be arranged in the descending order of $\mathrm{PM}>$ $\mathrm{FYM}>\mathrm{CO}>\mathrm{MR}$. The hydraulic conductivity values followed the same trend as the soil infiltration rate. The obtained $\mathrm{HC}$ results coincide with those of soil bulk density and soil porosity that previously mentioned (Table 4). Increase in the hydraulic conductivity of the soil as a result of application soil amendments attributed to its positive effect on the reduction the soil bulk density and consequently the increase in the soil porosity. Improving the soil bulk density and porosity through causes application soil amendments faster movement of water through the soil profile that is inverted on the soil infiltration rate and hydraulic conductivity. Furthermore, a reduction the soil bulk density might be due to increased soil bio-pores and soil aeration, higher soil organic carbon content, and better soil aggregation by the application of organic manures that ultimately improved the soil porosity and water holding capacity as well (Gangwar et al., 2006). Ouyang et al. (2013) reported that dairy manure improved the soil tillage and porosity, increased soil infiltration rates, saturated hydraulic conductivity, crop yields, soil organic matter and aggregation as well as decreased the soil bulk density. Lehmann and Stephen (2015) as found that the hydraulic conductivity of the soil enriched with organic material was mainly influenced by its size and soil particles. Furthermore, Lim et al. (2016) showed an increase in the hydraulic conductivity of soil after the application of organic materials of particles larger than the original soil particles. Improved (increased) hydraulic conductivity may also be the result of an improvement in the soil structure through the applied 
organic materials. Tokova et al. (2020) found that the values of saturated hydraulic conductivity increased with increasing the application level of biochar in most of the treatments with or without fertilization.

\subsection{Wheat grain and straw yield}

\subsubsection{Grain yield}

The results indicated that there was a significant increase in total wheat dry grain yield as a result of applying the different soil amendments compared to the control one (Table 7). The magnitude increase relied on the amendment type and its application level. The grain yield varied from 2.38 to 3.77 ton/fed since the lowest value was recorded in the first season for the control treatment and the highest value was found in the first season for the farmyard manure treatment applied at 40 ton/fed. On the average of both seasons, the grain yield ranged from 2.43 ton/fed for the control treatment to 3.72 ton/fed for PM 40 ton/fed. On the average of both seasons, the grain yield might be arranged in the descending order of $\mathrm{PM}>\mathrm{FYM}>\mathrm{MR}>$ $\mathrm{CO}>$ C. Meena et al. (2018) reported that there is a positive effect as a result of applying farmyard manure at rate of 10 ton/ ha on the wheat grain yield that increased by $62.74 \%$ than the control.

Table (7): Application effect of soil amendments on wheat yield (grain and straw) during both growth seasons of 2017/18 and 2018/19.

\begin{tabular}{|c|c|c|c|c|c|c|c|}
\hline \multirow{2}{*}{ Treatment } & \multirow{2}{*}{$\begin{array}{c}\text { Application } \\
\text { level (ton/fed) }\end{array}$} & \multicolumn{3}{|c|}{ Grain yield (ton/fed) } & \multicolumn{3}{|c|}{ Straw yield (ton/fed) } \\
\hline & & $2017 / 18$ & $2018 / 19$ & Mean & $2017 / 18$ & $2018 / 19$ & Mean \\
\hline Control (C) & 0 & 2.38 & 2.48 & 2.43 & 2.46 & 2.92 & 2.69 \\
\hline \multirow{3}{*}{$\begin{array}{l}\text { Poultry manure } \\
\text { (PM) }\end{array}$} & 20 & 3.71 & 3.70 & 3.71 & 5.00 & 5.38 & 5.19 \\
\hline & 40 & 3.70 & 3.74 & 3.72 & 5.75 & 6.01 & 5.88 \\
\hline & Mean & 3.71 & 3.72 & 3.71 & 5.38 & 5.70 & 5.54 \\
\hline \multirow{3}{*}{$\begin{array}{l}\text { Farm yard manure } \\
(\text { FYM) }\end{array}$} & 20 & 3.68 & 3.52 & 3.60 & 5.24 & 5.28 & 5.26 \\
\hline & 40 & 3.77 & 3.62 & 3.70 & 6.26 & 5.97 & 6.12 \\
\hline & Mean & 3.73 & 3.57 & 3.65 & 5.75 & 5.63 & 5.69 \\
\hline \multirow{3}{*}{ Compost (CO) } & 20 & 3.48 & 3.51 & 3.50 & 4.63 & 4.98 & 4.81 \\
\hline & 40 & 3.67 & 3.61 & 3.64 & 4.67 & 5.01 & 4.84 \\
\hline & Mean & 3.58 & 3.56 & 3.57 & 4.65 & 5.00 & 4.82 \\
\hline \multirow{3}{*}{ Mud rocks (MR) } & 20 & 3.55 & 3.46 & 3.51 & 4.55 & 4.94 & 4.75 \\
\hline & 40 & 3.63 & 3.57 & 3.60 & 5.36 & 5.42 & 5.39 \\
\hline & Mean & 3.59 & 3.52 & 3.55 & 4.96 & 5.18 & 5.07 \\
\hline \multirow{3}{*}{ LSD 0.05} & treatment $(\mathrm{A})$ & 0.12 & 0.08 & ------ & 0.56 & 0.42 & ------- \\
\hline & level (B) & NS & 0.09 & ------ & 0.19 & 0.16 & ------- \\
\hline & $\mathrm{A} * \mathrm{~B}$ & 0.26 & 0.25 & ------- & 0.51 & 0.41 & ------- \\
\hline
\end{tabular}

\subsubsection{Straw yield}

Generally, there were significant increases in the straw yield as a result of applying the studied soil amendments compared to the control treatment (Table
7). The magnitude of the straw yield increase relied on conditioner type and its application level. The mean straw yield of both growth seasons varied from 2.69 ton/fed for the control treatment to 6.12 ton/fed for FYM applied at 40 ton/fed 
level. Therefore, the soil amendments could be arranged in the descending order of $\mathrm{FYM}>\mathrm{PM}>\mathrm{MR}>\mathrm{CO}>\mathrm{C}$ with respect to the mean straw yield. It was noticed that the relative changes in straw yield was more pronounced at the high level than that in the low one. Furthermore, it was observed relative increase in the mean straw yield of $105.76,111.43,79.28$ and $88.38 \%$ for PM, FTM, CO and MR, respectively found to control treatment. Similar result was obtained by Meena et al. (2018) who concluded that the farmyard manure application combined with recommended fertilizers increased the straw yield by about $135 \%$ than the control. It might be concluded that sustainable agricultural in the new reclaimed area relies on natural soil amendments application to achieve suitable crop production. Since the new lands own very low organic matter, high salinity and alkalinty, short fertile nutrients and have inferior physical properties and moisture characteristics. Results of this investigation showed that soil hydro-physical and biological properties of the reclaimed area improved by adding different natural soil amendments that bring it under the umbrella of agricultural land. Manures application has significant influence on wheat productivity and soil hydrophysical properties. Manure efficacy regarding morphological indices and wheat yield was found as PM > FYM > $\mathrm{CO}>\mathrm{MR}$. The study verified that adding poultry manure as a soil conditioner at 40 ton/ fed. was the best agricultural practice that improve soil hydro-physical and biological properties of the new reclaimed land. It is, therefore, recommended that natural organic soil amendments manure such as poultry manure, farmyard manure and compost could be a viable tool in the improvement and stabilization of coarse textured, fragile new reclaimed of low organic matter. The use of any type of applied soil amendments depends on its accessibility and handle.

\section{References}

Adesodun, J. K., Mbagwu, J. S. C. and Oti, N. (2005), "Distribution of carbon nitrogen and phosphorus in water stable aggregates of an organic waste amended ultisol in southern Nigeria", Bioresource Technology, Vol. 96, pp. 509-516.

Adeyemo, A. J., Akingbola, O. O. and Ojeniyi, S. O. (2019), "Effects of poultry manure on soil infiltration, organic matter contents and maize performance on two contrasting degraded alfisols in southwestern Nigeria", International Journal of Recycling of Organic Waste in Agriculture, Vol. 8, pp. 73-80.

Adugna, G. (2016), "A review on impact of compost on soil properties, water use and crop productivity", Academic Research Journal of Agricultural Science and Research, Vol. 4 No. 3, pp. 93-104.

Agbede, T. M., Adekiya, A. O. and 
Ogeh, J.S. (2013), "Effects of organic fertilizers on yam productivity and some soil properties of a nutrient-depleted tropical Alfisol", Archives of Agronomy and Soil Science, Vol. 59 No. 4-6, pp. 803-822.

Agbede, T. M., Ojeniyi, S. O., Adeyemo, A. J. (2008), "Effect of poultry manure on soil physical and chemical properties, growth and grain yield of sorghum in South West Nigeria", American-Eurasian Journal of Sustainable Agriculture, Vol. 2 No. 1, pp. 72-77.

Akanbi, W. B., Akande, M. O., Adediran, J. A. (2005), "Suitability of composted Maize straw and mineral nitrogen fertilizer for tomato production", Journal of Vegetable Science, Vol. 11, pp. $57-65$.

Awad, M. Y. M., Moustafa-Farag, M., Wei, L., Huang, Q. and Liu, Z. (2020), "Effect of garden waste biochar on the bioavailability of heavy metals and growth of Brassica juncea (L.) in a multicontaminated soil", Arabian Journal of Geosciences, Vol. 13, pp. 439.

Awad, M. Y. M. (2001), Effect of some organic compounds on soil properties and plant growth, M.Sc. Thesis, Faculty of Agriculture, Minufiya University, Egypt.

Awad, M. Y. M. (2016), "Poultry manure and humic acid foliar applications impact on caraway plants growth on a clay loam", Journal of Soil
Sciences and Agricultural Engineering, Vol. 7 No. 1, pp. 1-10

Bameri, M., Abdolshahi, R., Nejad, G. M., Yousefi, K. and Tabatabaie, S. M. (2012), "Effect of different microelement treatment on wheat (Triticum aestivum L.) growth and yield", International Research Journal of Applied and Basic Sciences, Vol. 3 No. 1, pp. 219-223.

Chauvin, G. M., Flerchinger, G. N., Link, T. E., Marks, D., Winstral, A. H. and Seyfried, M. S. (2011), "Long-term water balance and conceptual model of a semi-arid mountainous catchment", Journal of Hydrology, Vol. 400 No. 1-2, pp. 133-143.

El-Farghal, W. M. and El-Sherif, A. A. (2012), "Effect of rice Straw compost and vinasse applications on some soil properties and yield of Egyptian clover", Journal of Soil Sciences and Agricultural Engineering, Vol. 3 No. 11, pp. 1057-1069.

Eldardiry, E. I. and Abd El-Hady, M. (2015), "Effect of different soil conditioners application on some soil characteristics and plant growth I-Soil moisture distribution, barley yield and water use efficiency", Global Advanced Research Journal of Agricultural Science, Vol. 4 No. 7, pp. 361-367.

Gangwar, K. S., Singh, K. K., Sharma, S. K. and Tomar, O. K. (2006), "Alternative tillage and crop residue management in wheat after rice in 
sandy loam soils of indogengetic plains", Soil \& Tillage Research, Vol. 88, pp. 242-252.

Garg, S. and Bahla, G. S. (2008), "Phosphorus availability to maize as influenced by organic manures and fertilizer $\mathrm{P}$ associated phosphatase activity in soils", Bioresour Technology, Vol. 99 No. 13, pp. 5773-5777.

ECES and ENCC (2014), The Future of Agriculture in Egypt, Comparative Study of Organic and Conventional Food Production Systems in Egypt, Version 1.0, Egyptian Council for Economic Studies (ECES) and the Egyptian National Competitiveness Council (ENCC), Cairo, Egypt.

Habashy, N., Ewees, M. S. A. (2011), "Improving productivity of zucchini squash grown under moderately saline soil using gypsum, organostimulants and AM-fungi", Journal of Applied Sciences Research, Vol. 7 No. 12, pp. 2112-2126.

Hillel, D. (1982), Introduction to Soil Physics, Academic Press, New York, USA.

Karbout, N., Moussa, M., Gasmi, I. and Bousnina, H. (2015), "Effect of clay amendment on physical and chemical charac $\neg$ teristics of sandy soil in arid areas: the case of ground South - Eastern Tunisian", Applied Scientific Reports, Vol. 11, pp. 4348.

Klute, A. (1986), Methods of soil analysis, Part 1: Physical and mineralogical methods, $2^{\text {nd }}$ edition, American Society of A gronomy Inc., Madison, Wisconsin, USA.

Kobierski, $\quad$ M., KondratowiczMaciejewska, K., Banach-Szott, M., Wojewódzki, P. and Castejón, J. M. P. (2018), "Humic substances and aggregate stability in rhizospheric and non-rhizospheric soil", Journal of Soils and Sediments, Vol. 18 No. 8, pp. 2777-2789.

Lehmann, J. and Stephen, J. (2015), "Biochar effect on soil hydrology", In Biochar for Environmental Management: Science, Technology and Implementation; Rountledge, Taylor \& Francis Group, London, UK, pp. 543-563.

Lehmann, J., Matthias, C. R., Janice, T., Caroline, A., Masiello, W. and Hockaday, C. D. C. (2011), "Biochar effects on soil biota e A review", Soil Biology \& Biochemistry, Vol. 43, pp. 18121836.

Li, J. T., Zhong, X. L., Wang, F. and Zhao, Q. G. (2011), "Effect of poultry litter and livestock manure on soil physical and biological indicators in a rice-wheat rotation system", Plant, Soil and Environment, Vol. 8, pp. 351-356.

Lim, T. J., Spokas, K., Feyereisen, G. and Novak, J. (2016), "Predicting the impact of biochar additions on soil hydraulic properties", Chemosphere, Vol. 142, pp. 136- 
144.

Lu, S. G., Sun, F. F. and Zong, Y. T. (2014), "Effect of rice husk biochar and coal fly ash on some physical properties of expansive clayey soil (Vertisol)", Catena, Vol. 114, pp. 37-44.

Meena, K. B., Alam, M. S., Singh, H., Bhat, M. A., Singh, A. K., Mishra, A. K., and Thomas, T. (2018), "Influence of farmyard manure and fertilizers on soil properties and yield and nutrient uptake of wheat", International Journal of Chemical Studies, Vol. 6 No. 3, pp. 386-390.

Miglierinaa, A. M., Iglesiasa, J. O., Laurenta, G. C., Rodrigueza, R. A., Ayastuya, M. E., Lobartinia, J. C. (2015), "Application of compost to different texture soils: Effect on soil properties and productivity of lettuce crop", Acta Horticulturae, Vol. 1076, pp. 97-104.

Nyangani, E. T. (2010), "Effect of combined application of organic manure and chemical fertilizers on soil properties and crop yields", Nigerian Journal of Science, Technology, and Environmental Education, Vol. 3, pp. 28-32.

O’Neal, A. M. (1952), "A key for evaluating soil permeability by means of certain field clues", Soil Science Society of America Journal, Vol. 16, pp. 312-315.

Ouyang, L., Tang, W. J. and Zhang, R. (2013), "Effects of biochar amendment on soil aggregates and hydraulic properties", Journal of Soil Science and Plant Nutrition, Vol. 13, pp. 991-1002.

Page, A. L., Miller, R. H. and Keeney, D. R. (1982), Methods of Soil Analysis, $2^{\text {nd }}$ Edition, Amercen Society of Agronomy, Madison, WI., USA.

Šimanský, V. (2016), "Effects of biochar and biochar with nitrogen on soil organic matter and soil structure in Haplic Luvisol", Acta fytotechnica et zootechnica, Vol. 19, pp. 129-138.

Šimanský, V., Polláková, N. and Jonczak, J. (2016), "Is better minimum than standard mouldboard ploughing tillage from viewpoint of the pore-size distribution and soil water retention characteristic changes", Agronomical Research in Moldavia, Vol. 167, pp. 17-26.

Šimanský, V. and Jonczak, J. (2020), "Aluminium and iron oxides affect the soil structure in a long-term mineral fertilised soil", Journal of Soils and Sediments, Vol. 20, pp. 2008-2018.

Syed, M. D. and Touhidul, M. (2009), Effect of clay treatment on the productivity of sandy soil for wheat cultivation, Faculty of Agricultural Engineering \& Technology, Bangladesh Agricultural University, Mymensingh, Bangladesh.

Tayebeh, A., Abass, A. and Seyed, A. K. (2010), "Effect of organic and inorganic fertilizers on grain yield 
and protein banding pattern of wheat", Australian Journal of Crop Science, Vol. 4 No. 6, pp. 384-389.

Toková, L., Igaz, D., Horák, J. and Aydin, E. (2020), "Effect of biochar application and re-application on soil bulk density, porosity, saturated hydraulic conductivity, water content and soil water availability in a silty loam Haplic Luvisol", Agronomy, Vol. 10, pp. 1005.

Vereecken, H., Huisman, J. A., Bogena, H., Vanderborght, J., Vrugt, J. A. and Hopmans, J. W. (2008), "On the value of soil moisture measurements in vadose zone hydrology: a review", Water Resources Research, Vol. 44, pp. 21.

Wafaa, M. A. S., Hanaa, A. Z. and Wagida, Z. H. (2016), "Effectiveness of soil amendments application on sandy soil properties and peanut productivity", Egyptian Journal of Soil Science, Vol. 56 No. 3, pp. 519-535.
Wanniarachchi, D., Mumtaz, C., Raymond, T., Vanessa, K. and Lakshman, G. (2019), "Impact of soil amendments on the hydraulic conductivity of boreal agricultural podzols", Agriculture, Vol. 9, pp. 133.

Westerman, P. W. and Bicudo, J. R. (2005), "Management considerations for organic waste use in agriculture", Bioresource Technology, Vol. 96, pp. 215-221.

Zahir, Z. A., Afzal, A., Ajmal, M., Naveed, M., Asghar, H. N. and Arshad, M. (2007), "Nitrogen enrichment of composted organic wastes for improving growth, yield and nitrogen uptake of wheat", Soil and Environment, Vol. 26 No. 1, pp. 15-21. 